\section{Ethical Lingua}

Journal of Language Teaching and Literature

ISSN 2355-3448 (Print)

ISSN 2540-9190 (Online)

Volume 5, Number 2, August 2018 pp. $219-237$

\title{
A Discourse Analysis of German Fairy Tale "Rapunzel" Written by the Brothers Grimm
}

\author{
Andi Tenrisanna Syam \\ risannasyam23@gmail.com
}

Institut Agama Islam Negeri (IAIN) Palopo, Indonesia

Received : 2 July 2018; Accepted: 3 September 2018

URL : : http://journal.uncp.ac.id/index.php/ethicallingua/article/view/1037

DOI : : https://doi.org/10.30605/ethicallingua.v5i2.1037

\begin{abstract}
The objectives of this study are to describe the ki is of infor ration in Rapunzel and to describe deixis, grammatical and in cal cohesion of Rapunzel. This study belonged to the qualitativ dy that vas focused on the concrete phenomenon of the written mrerials. "ne technique of data collection were: the writer observed the $f$ atures that occur in the fairy tale then took it to note. The writer found the (1) title can be expounded by a short clause, phrase, or sentence, ( 2 ) the aponure is expounded by a clause, sentence, or paragraph, (3) the sta paragraph containing desc ve cluses, clauses with past completed action and identification o. se or noun phrase, (4) the author used third person pronouns she and he, 5) some nouns or pronouns were omitted in the second of coor inc clauses; (6) there were 64 sentences used additive conjunction and sonte so sed comparative conjunction but, however, the conjunctio ne cher..nor, or and if is only used once; (7) the authors only repeated wo will and hair; (8) the authors used words bird and cat in whicb re a hyponym of animal; and (9) the synonyms words are grief, misery, h d, issten.
\end{abstract}

Keywords: discourse analysis; deixis; grammatical; lexical cohesion 